\title{
Anaerobic digestion and microwave pyrolysis techniques for recycling organic wastes
}

\author{
Krystian Butlewski ${ }^{12}$ \\ DOI: dx.doi.org/10.14314/polimery.2019.11.10
}

\begin{abstract}
Two promising techniques - anaerobic digestion (AD) and microwave pyrolysis (MP) - have been presented in this work for possible recycling of organic waste. The main products of AD are biogas and digestate, which can be utilized for production energy, fuels and valuable materials. MP products are gases, liquids and char, which can be used as substrates for producing hydrogen, biodiesel, kerosene, and activated carbon. MP provides fast heating and can be used for various material waste blends including biomass - plastic mixtures. AD and MP can be combined for a synergic effect with respect to system efficiency.
\end{abstract}

Keywords: microwave pyrolysis, anaerobic digestion, organic waste, recycling.

\section{Beztlenowa fermentacja i mikrofalowa piroliza w recyklingu odpadów organicznych}

Streszczenie: $\mathrm{W}$ pracy przedstawiono dwie nowoczesne techniki - beztlenową fermentację (AD) i mikrofalową pirolizę (MP) w kontekście możliwości ich wykorzystania w recyklingu odpadów organicznych. Głównymi produktami AD są biogaz i poferment stosowane w produkcji energii, paliw i wartościowych materiałów. Produktami MP są natomiast gaz, ciecz i substancja węglowa stanowiące materiał wejściowy do produkcji wodoru, biodiesla, nafty i węgla aktywowanego. Technika MP zapewnia szybkie nagrzewanie i może być wykorzystana w wypadku różnych mieszanin materiałów odpadowych, m.in. mieszanin biomasy z „plastikami”. Instalacje AD i MP mogą być stosowane łącznie w celu uzyskania synergii wytwarzania energii, paliw i wartościowych wyrobów.

Słowa kluczowe: piroliza mikrofalowa, beztlenowa fermentacja, odpady organiczne, recycling.

Organic waste and by-products are good substrates from which to obtain bioenergy vectors, namely biofuels, heat and power, as well as valuable products like chemical substances, materials, fibers, plastics, fertilizers, food, feed, pharmaceuticals, etc. There are mechanical, chemical, thermal, thermochemical and biological methods for converting them into those products. A number of studies have been carried out to obtain the best possible techniques for particular substrates. Among this anaerobic digestion and pyrolysis plays important roles. The anaerobic digestion method for converting waste into valuable products has developed rapidly in the last two decades. In EU there are about $18000 \mathrm{AD}$ installations, from which more than 13000 are for agricultural waste and by-products. The remaining ones are for municipal organic waste, sewage sludge and food and industrial organic waste. The main products of the $\mathrm{AD}$ process are biogas and digestate, which can be utilized for energy production, fuels or valuable products. Pyrolysis has

1) Institute of Technology and Life Sciences, Hrabska 3, Falenty, 05-090 Raszyn, Poland,

e-mail: k.butlewski@itp.edu.pl been known for a long time, but not until the last decade it is proved that it could be successfully used as a technique for converting different materials including biomass, plastics and rubber, into syngas and biochar. In recent years, special attention has been paid to microwave pyrolysis, since by using this technique more gas product can be obtained and the process is cleaner than in the conventional pyrolysis, because much less tar is formed. In addition to this, a synergic effect can be obtained by combing microwave pyrolysis with anaerobic digestion, which has been pointed out in this work.

\section{ANAEROBIC DIGESTION FOR RECYCLING ORGANIC WASTE FOR METHANE PRODUCTION}

Anaerobic digestion (AD) is a biological technology for decomposing organic matter by a variety of microorganisms in an anaerobic condition with the aim of producing biogas composed mainly of methane (30-70 vol. \%) and carbon dioxide (30-70 vol. \%) with traces of other gases such as hydrogen, ammonia and hydrogen sulphide. The $\mathrm{AD}$ process consists of four steps, namely hydrolysis, fermentation, acetogenesis, and methanogenesis as shown 
in Fig. 1. In the hydrolysis process, extracellular enzymes reduce insoluble complex organic polymers such as carbohydrates, proteins and lipids to amino acids, fatty acids and sugars. The reduced compounds are then converted by fermentative bacteria to a mixture of short-chain volatile fatty acids and other minor products, such as carbon dioxide, hydrogen and acetic acid. Acetogenic bacteria further convert the organic acid to acetone, carbon dioxide, and hydrogen, which are the direct substrates for methane production. The final step of AD is methanogenesis, where a variety of methanogenic bacteria con-

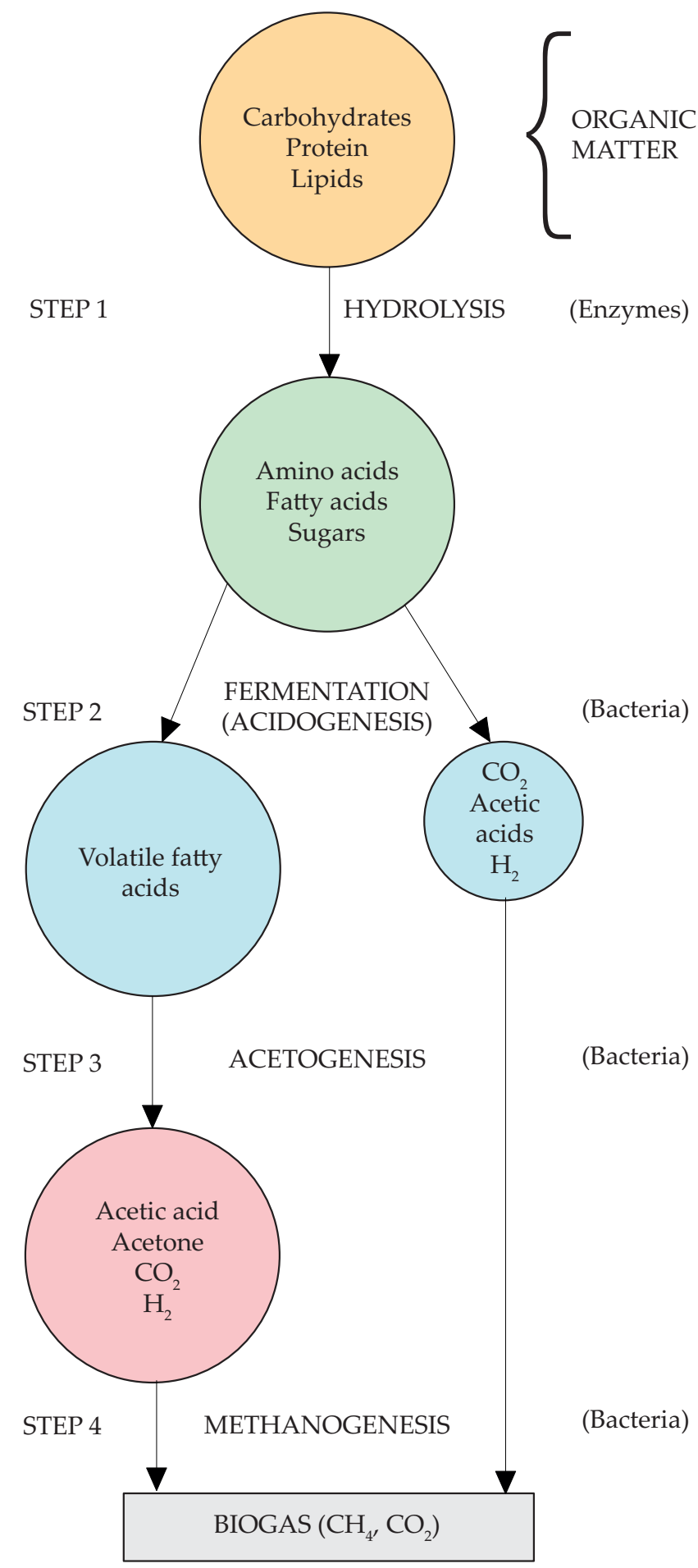

Fig. 1. The anaerobic digestion process flow sume acetate and hydrogen to produce biogas (methane and carbon dioxide) [1].

Organic waste material such as livestock waste and manure, organic municipal solid waste (MSW), food waste, industrial waste, sewage sludge and agricultural residues, can be potentially processed in an anaerobic digestion (AD) installation to produce biogas and digestate (Fig. 2). There are different possible routes for biogas utilization. The most common way to generate electricity and heat is to use a Combined Heat and Power generator (CHP), which consists of an internal combustion engine connected with a power generator and heat recovery system. This technology is suitable for small biogas plants with an installed electric power up to $200 \mathrm{~kW}$. Above that power, it is more economical and more environmentally friendly to use a fuel cell. The technical advantage of a fuel cell is its high efficiency, lack of GHG emissions, and quiet operation when compared with the combustion engine. At present, in most cases Solid Oxide Fuel Cells (SOFC) are used for biogas conversion into energy, while the Molten Carbonate Fuel Cell (MCFC) has not been used in the industrial scale yet $[2,3]$. It is worth mentioning that the MCFC operating temperature is around $650{ }^{\circ} \mathrm{C}$, while SOFC requires a higher temperature, of up to $1000^{\circ} \mathrm{C}$. In addition to this, MCFC uses carbon dioxide for its operation, providing a reduction of this gas present in the surrounding environment. A new concept of biogas utilization is to build a local network a certain distance from the biogas installation which will be filled with biogas without upgrading to biomethane [4]. Biogas can also be upgraded to biomethane by different mechanical, thermochemical and biological methods and then injected into the existing natural gas network, or following compression or liquefaction, it can be used as a transport fuel [5, 6]. The other product of anaerobic fermentation is digestate. If substrates are of agricultural origin, it can be directly used as a fertilizer, provided that the number of elements and compounds would not exceed the permissible limits for a soil. In other possible routes, it can be separated into solid and liquid fractions. Solid fraction can be used as a solid fertilizer or can be converted into energy carriers in the form of pellets or briquettes (Fig. 2).

\section{MICROWAVE-ASSISTED PYROLYSIS CONVERSION TECHNIQUE}

There are three thermochemical conversion techniques for utilization waste organic materials according to the oxygen contribution to the process. They are combustion, in which material is completely oxidized, gasification with partial oxidation, and pyrolysis, in which material degradation appears without oxygen. The pyrolysis process converts raw material into intermediate products, which can be classified as solid, liquid and gaseous substances. Solid substances are mainly different forms of carbon, while liquid products are heavy molecular weight gases that condense when cooled down. Gaseous 


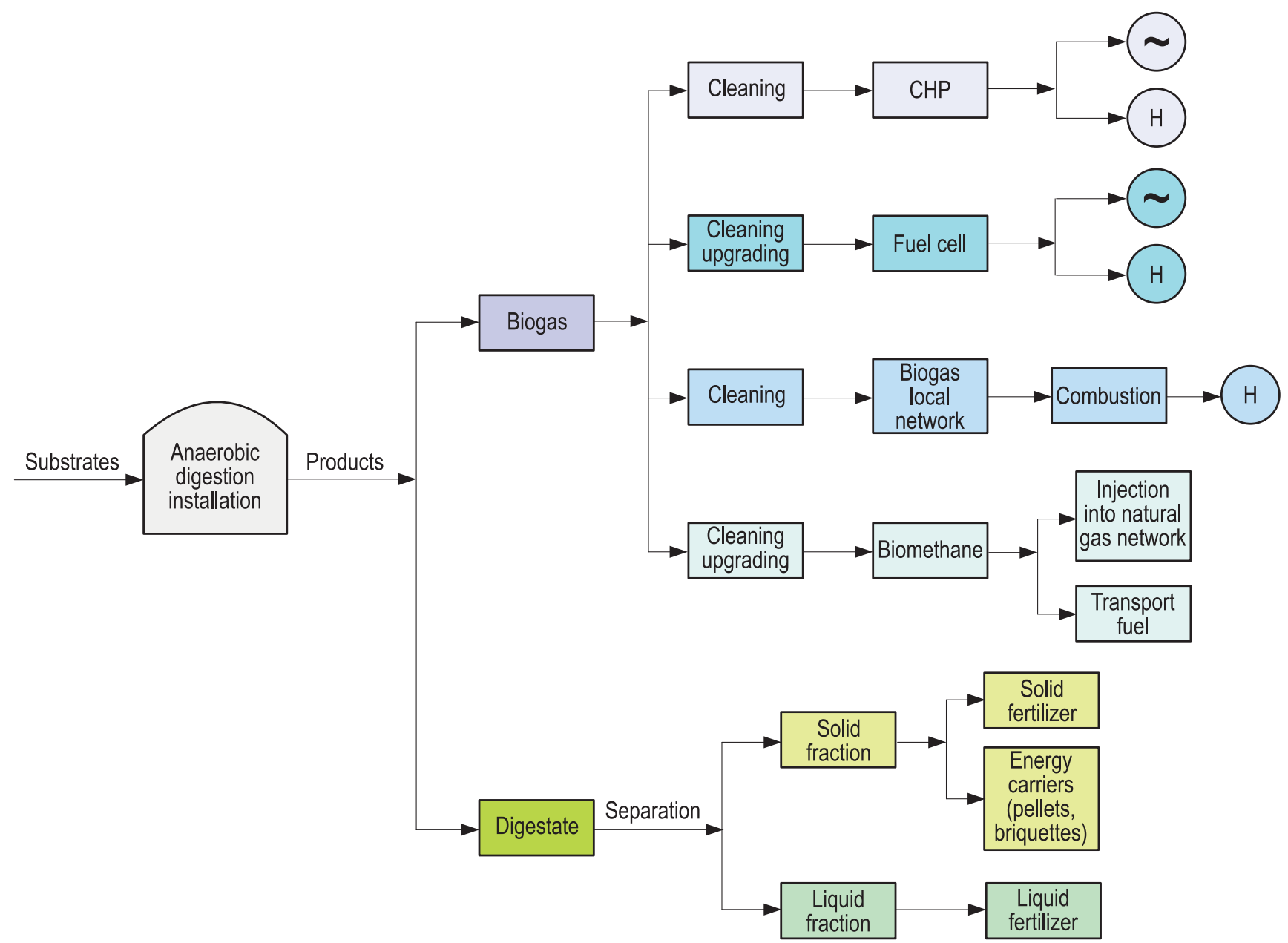

Fig. 2. Possible utilization of product from an anaerobic digestion installation: $\mathrm{H}$ - heat, $\mathrm{CHP}$ - combine heat and power generation

products are light molecular weight combustible gasses, such as hydrogen, carbon oxide, methane, ethane, ethene, propane, propene, etc.

Composition of the pyrolysis intermediate products depends on raw material and process parameters. Properties of raw materials imply pyrolysis characteristics, including an initial degradation temperature, conversion time and volatile releasing rate. Process parameters include process temperature, heating rate, residence time of vapours present in the reactor and the type of reactor. Depending on these parameters, the pyrolysis process can be divided into three categories, namely slow, fast and flash pyrolysis. In general, fast and flash pyrolysis generate more gaseous substances than slow pyrolysis. There are three types of reactors with regard to heat delivery to the processing materials, namely thermal, plasma and microwave. In thermal reactors, the heat flows from the external source to the material, e.g. from the reactor outer surface heated by the electric resistance or flame. In plasma reactors, an arc is produced between two electrodes using a DC power supply. The required process temperature is achieved rapidly due to the high temperature $\left(>5000^{\circ} \mathrm{C}\right)$ especially near the electric arc. In microwave reactors (Fig. 3) electromagnetic waves in the frequency range of $300-3000 \mathrm{MHz}$ are gen- erated by magnetrons to heat dielectric materials. From this range, a few frequencies were chosen by the Federal Communications Commission for industrial use (not to interfere with mobile telephone frequencies), from which the commonly used frequencies for microwave application are 0.915 and $2.45 \mathrm{GHz}$.

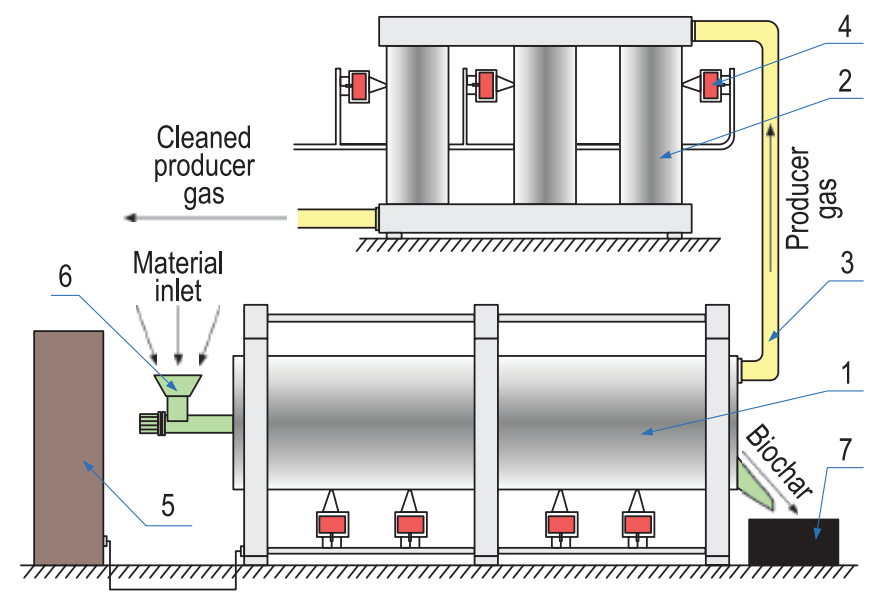

Fig. 3. Microwave pyrolysis installation: 1 - reactor, 2 - microwave cleaning unit, 3 - pipe for producer gas flows to the microwave cleaning unit, 4 - magnetrons, 5 - electric cabinet, 6 - reactor material inlet, 7 - biochar container 
a)

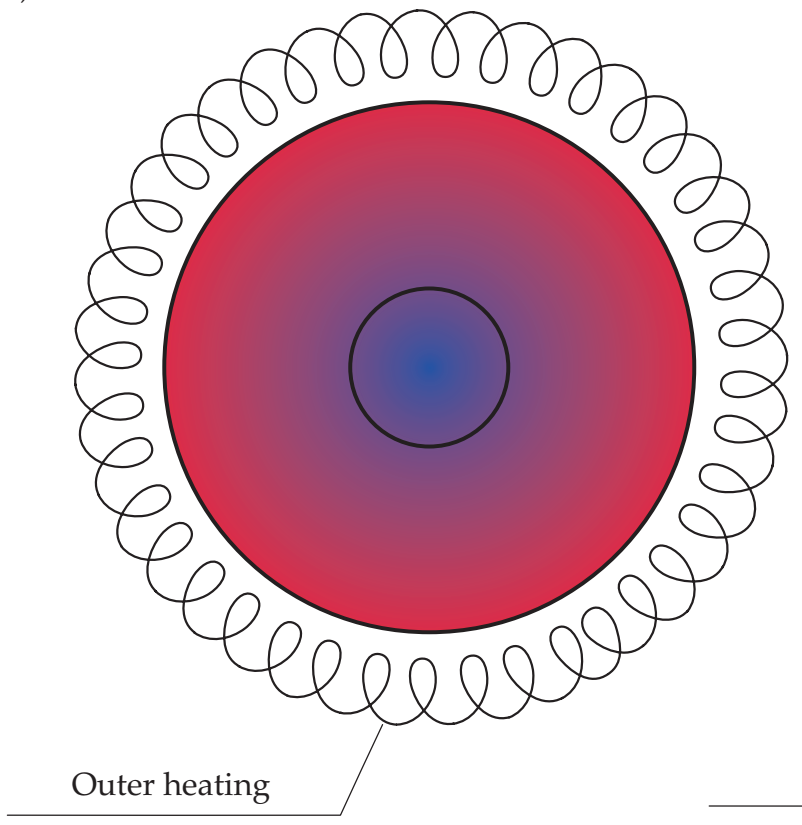

b)

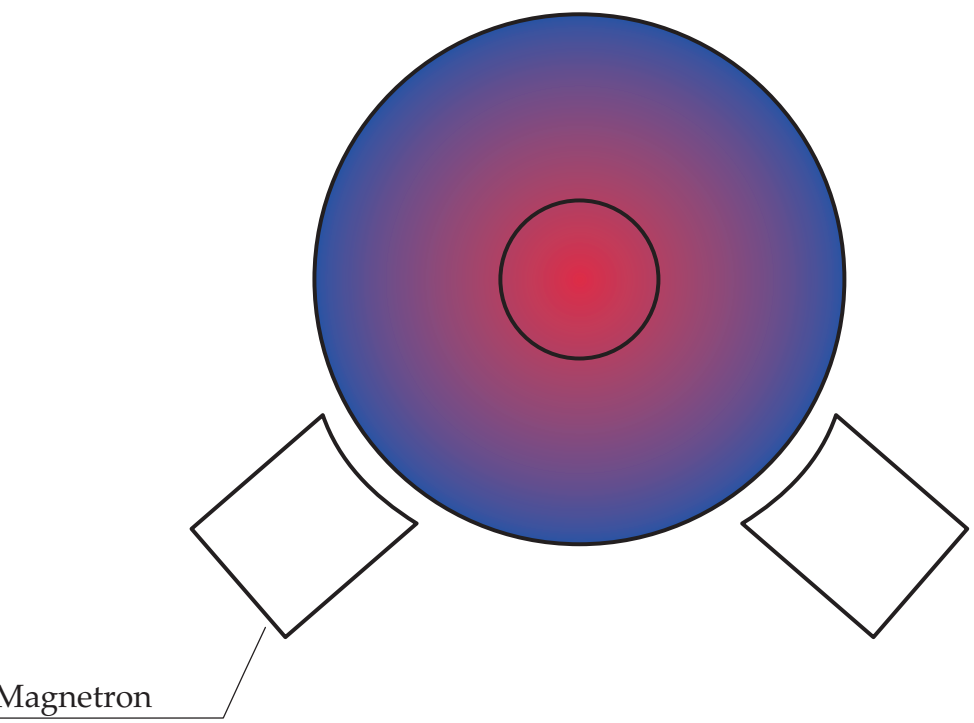

Temperature

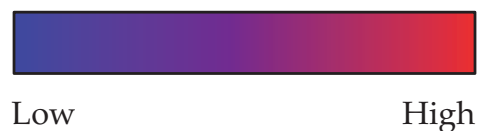

Fig. 4. Temperature distribution in a cross-section of a reactor with: a) conventional heating, b) microwave heating; the inner circle represents a cross-section of a product

There are three categories of materials with respect to their specific interaction with microwave field. The first represents electric insulator materials, were microwaves pass through them. The following material examples belong to this group: quartz glass, porcelain, ceramics, and Teflon. The second category is electric conductors, where microwaves reflect from them. Metals and graphite belong to this group of materials. The third group is lossy dielectrics, which are materials that exhibit dielectric losses, which in turn results in heat generation in an oscillating electromagnetic field (e.g. water, biomass). Absorption of microwave radiation causes material heating, due to energy dissipation as a result of molecular interaction with the electromagnetic field. Microwave heat-

$\mathrm{T}$ a b 1 e 1. Major differences in conventional and microwave heating properties

\begin{tabular}{|c|c|}
\hline Conventional heating & Microwave heating \\
\hline Heat transfer process & Energy conversion process \\
\hline $\begin{array}{l}\text { No additives are needed } \\
\text { for material conversion }\end{array}$ & $\begin{array}{l}\text { Electromagnetic field } \\
\text { absorbers are needed } \\
\text { for some materials }\end{array}$ \\
\hline $\begin{array}{l}\text { Any fuels or energy source } \\
\text { can be used for heating } \\
\text { material inside a reactor }\end{array}$ & $\begin{array}{l}\text { Electric energy is needed to } \\
\text { generate microwaves }\end{array}$ \\
\hline $\begin{array}{l}\text { Material heating process } \\
\text { is long }\end{array}$ & $\begin{array}{c}\text { Material heating process } \\
\text { is short }\end{array}$ \\
\hline
\end{tabular}

ing is an energy conversion process, rather than a heat transfer process. The temperature distribution in a cross-section of reactors with thermal and microwave heating is shown in Fig. 4.

The main differences occurring between conventional and microwave heating are summarized in Table 1.

\section{DIFFICULT MATERIALS RECYCLING BY USING THE PYROLYSIS-ASSISTED MICROWAVE TECHNIQUE}

The microwave pyrolysis technique can be used for material with a high tangent loss factor $(\tan \delta)$, often named the dissipation factor, which indicates sensitivity to microwave energy and is defined as the ratio of dielectric loss factor and dielectric constant, as shown in equation (1).

$$
\tan \delta=\frac{\varepsilon^{\prime \prime}}{\varepsilon^{\prime}}
$$

where: $\varepsilon^{\prime \prime}$ - dielectric loss factor, indicating electromagnetic radiation conversion efficiency to heat, $\varepsilon^{\prime}$ - dielectric constant, indicating molecules ability to be polarized by the electric field.

Plastic materials have low tangent loss factor $(\tan \delta)$, therefore an absorber with a high tan $\delta$ has to be added to make microwave pyrolysis possible, due to the ab- 
sorber heating and transferring this energy to plastic processing. Typical absorbers used for microwave plastics conversion are carbon, zeolites, metal oxides or various salts [7].

Microwave heating can be used for mono-, co- and multi-pyrolysis processes, where it refers to one, two and more type of substrates used simultaneously in a reactor, respectively.

A mono-pyrolysis process for used baby diapers has shown the great potential in transforming this substrate into liquid oil and char products [8]. A used baby diaper consists of plastic materials (polyolefins) and cellulose. They had been transformed into liquid oil (43 wt \%), gasses (29 wt \%) and solid residue (28 wt \%) products. The liquid oil contained esters, alkanes and alkenes which can be used as fuel, chemical additives or cosmetic products. The solid char contained a high amount of carbon and did not include sulphur. It can be used as a soil improvement substance or as an adsorbent in chemical processes. Waste tires were subject to microwave irradiation to analyse the process and products obtained [9]. Microwave pyrolysis ran for a shorter time than in a convenient process and products were solid residue containing up to 92 wt \% carbon, a low viscosity oil with the dynamic viscosity below $2.9 \mathrm{mPa} \cdot \mathrm{s}$, which included a large amount of single ring aromatic hydrocarbons, and a gas containing light hydrocarbons, hydrogen and only traces of nitrogen. The char, oil and gas had a high calorific value of $34 \mathrm{MJ} / \mathrm{kg}, 45 \mathrm{MJ} / \mathrm{kg}$ and $46 \mathrm{MJ} / \mathrm{kg}$, respectively. Corn-derived plastic bags (CDPB) were subjected to microwave assisted pyrolysis using two different absorbers - carbon and iron [10]. The liquid obtained was separated in three phases. The upper fraction contained a large amount of aromatic acid and phthalates, the medium one was mainly composed of water (70 wt \%), acids and alcohols, while the lower one included oligomers of those compounds presented in the upper fraction. Microwave conversion of the CDPB is a better waste treatment technique than anaerobic fermentation because it avoids digestate contamination with plasticizers present in those type of bags. Microwave pyrolysis of selected waste from electric and electronic equipment coming from end-of-life computers was carried out using a reactor working at $2.45 \mathrm{GHz}$ [11]. Carbon and iron were used as the process absorbers. A large number of liquid fractions (up to 76.6 wt \%) with a low density and viscosity with a high concentration of valuable substances such as styrene and xylene were obtained. Microwave pyrolysis of glycerol using carbon and nickel metal supported on HZSM-5 (zeolite) as absorbers and catalysts was carried out [12]. It was concluded that the use of different catalysts produced different compounds, mainly methanol, allyl alcohol, acrolein and hydrogen.

The waste microwave co-pyrolysis process has been developed to enhance the products yield and composition compared to the mono-pyrolysis process. It has been shown that the mixed waste biomass and plastics resi- dues can be converted into more valuable products than that obtained from pyrolysis of individual components. The higher heating value (HHV) of co-pyrolysis bio-oil obtained from biomass (rice husk, wood sawdust, groundnut shell, bagasse) and plastic (polypropylene, polystyrene) blends was high (38-42 MJ/kg) compared to bio-oil obtained only from biomass pyrolysis (20-30 MJ/kg) [13]. The presence of polystyrene boosted the production of aromatic hydrocarbons, while polypropylene promoted aliphatic hydrocarbons in co-pyrolysis bio-oil. The microwave co-pyrolysis energy efficiency of the above mentioned mixtures was high $(63-68 \%)$ and better than that obtained for the individual biomass pyrolysis. Energy efficiency is calculated by using the following expression (2):

$$
\text { Energy efficiency }(\%)=\left\{\frac{\text { Total energy of products }(J)}{\text { Total energy of feed }(J)+\text { Microwave energy } J)}\right\} \cdot 100 \%
$$

Microwave co-pyrolysis of waste cooking oil and waste polyolefins was examined for its potential to convert them into biofuel [14]. The process was performed in a vacuum environment and nitrogen atmosphere. Higher quality oil was obtained for the vacuum condition. This oil comprised more aliphatic and aromatics hydrocarbons and had a high energy content $42-49 \mathrm{MJ} / \mathrm{kg}$. Microwave catalytic co-pyrolysis of lignin and polypropylene showed increased yield and improved quality of bio-oil compared with lignin pyrolysis alone [15]. Aromatic and cycloalkanes were the main components of the oil from co-pyrolysis, which can be used as material for aviation fuel. Ex-catalytic microwave co-pyrolysis of bamboo and polypropylene with zeolite was investigated [16]. A significant synergistic effect was observed between bamboo and polypropylene, which caused a high bio-oil yield (61.62 wt \%) and increased the aromatic and naphthenic hydrocarbons suitable for the aviation fuel production.

The multi-pyrolysis process relies on using a mixture of different type of substrates, like biomass, plastic, glycerol, torrefied biomass, coal or others. No research concerning this type of process has been recorded in the scientific literature yet.

\section{PRODUCER GAS UTILIZATION}

There are three possible routes for utilizing a gas generated in a microwave pyrolysis reactor (Fig. 5). The first is to condense the producer gas and then to distil the liquid obtained into various fractions from which biofuels like biodiesel, heating oil and kerosene can be produced, as well as various valuable substances like those mentioned in the previous section. The second is to use producer gas directly for generating electric energy by means of a combustion engine or fuel cell. Waste heat concomitant electric energy production can be utilized for industrial or domestic heating or converted into electric energy using an Organic Rankine Cycle (ORC) sys- 


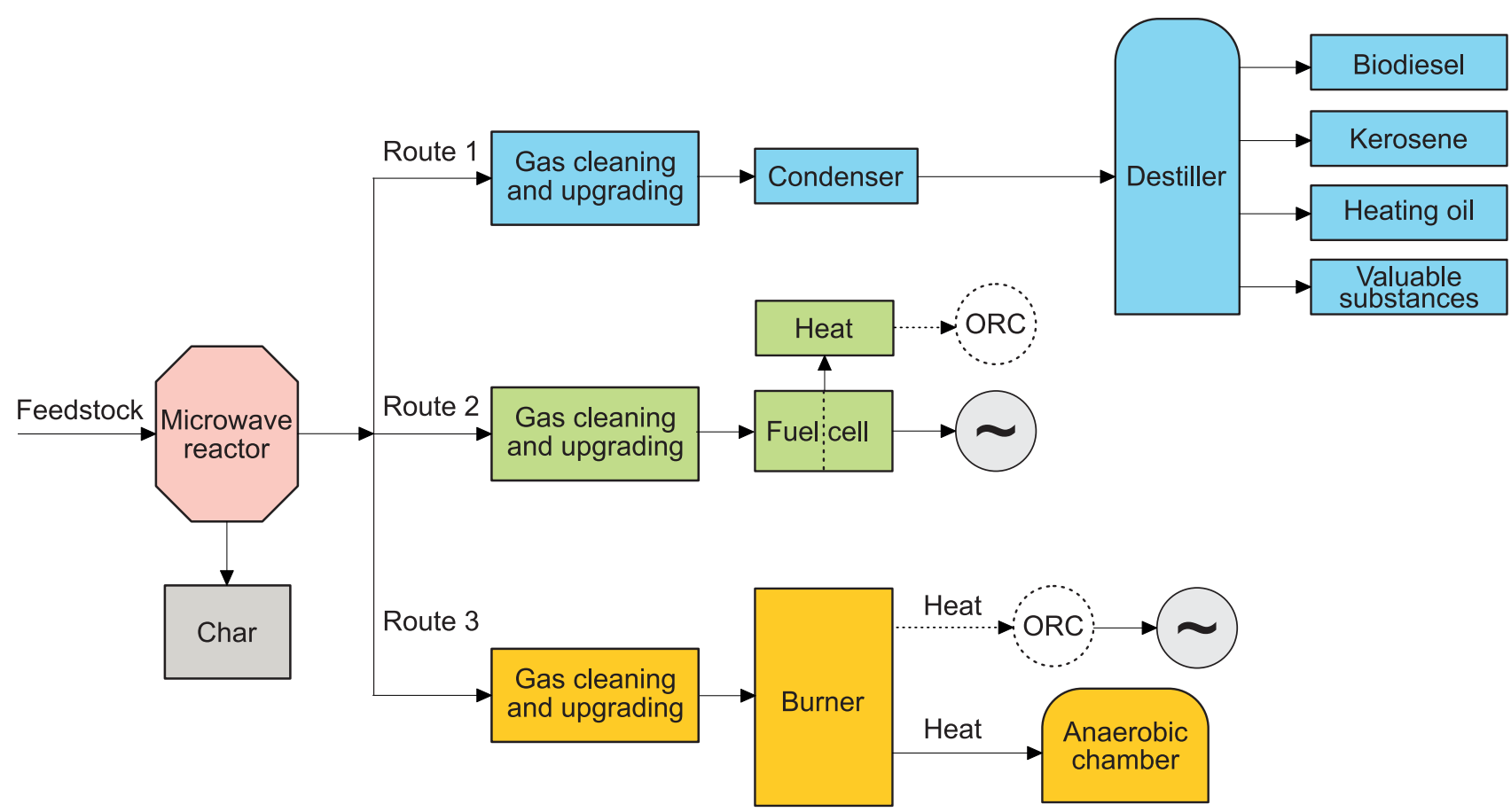

Fig. 5. Possible routes for utilizing of producer gas generated in a microwave reactor

tem or a Stirling engine. In both cases the producer gas has to be very carefully cleaned and upgraded. The third route is to burn it for generating heat for various applications like heating thermal oil in an ORC power station or water boiler for providing heat to an anaerobic chamber for producing biogas [17].

Researchers have shown $[17,18]$ the possible combination of waste gasification and anaerobic digestion for synergic effect with respect to surplus energy and heat utilization.

\section{CONCLUSIONS}

Microwave pyrolysis is a high temperature, thermochemical technique for converting organic waste into energy, fuels and valuable products. This technique is especially suitable for processing waste solid biomass and plastics, particularly for co-processing them, where biomass acts as the microwave's absorber in this process. On the other hand, anaerobic digestion provides a way for low temperature, biological conversion of various waste materials, which can be consumed and converted into biogas and digestate by microorganisms. Digestate is a valuable residual product that can be used as a fertilizer or can be transferred into an energy carrier in the form of pellets or briquettes. This material can be burned for heat generation or can be further converted into syngas in the aforementioned microwave pyrolysis reactor, which is a better solution for waste utilization from the environmental protection perspective. A very promising technique is to combine microwave pyrolysis and anaerobic digestion, which can provide better utilization of surplus energy, heat and emerging by-products.

\section{REFERENCES}

[1] Li Y., Park S., Zhu J.: Renewable and Sustainable Energy Reviews 2011, 15, 821. http://dx.doi:10.1016/j.rser.2010.07.042

[2] Saadabadi S.A., Thattai A.T., Fan L. et al.: Renewable Energy 2019, 134, 194. https://doi.org/10.1016/j.renene.2018.11.028

[3] Butlewski K.: Problemy Inżynierii Rolniczej 2013, 81, 109. http://www.itp.edu.pl/wydawnictwo/pir/ zeszyt_81_2013/K_Butlewski\%20\%20Ogniwa\%20 paliwowe\%20.pdf

[4] Butlewski K.: "Concept of Building an Experimental Biomass Refinery Plant in Poznan-Strzeszyn (Poland)", Proceedings 27th European Biomass Conference and Exhibition, Lisbon, Portugal, 27-30 May 2019.

http://www.etaflorence.it/proceedings/?detail=15942

[5] Goulding D., Power N.: Renewable Energy 2013, 53, 121.

https://doi.org/10.1016/j.renene.2012.11.001

[6] Butlewski K.: Problemy Inżynierii Rolniczej 2016, 92, 67. http://www.itp.edu.pl/wydawnictwo/pir/ zeszyt_92_2016/Butlewski\%20K\%20\%20Metody $\% 20$ uzdatniania\%20biogazu.pdf

[7] State R.N., Volceanov A., Muley P. et al.: Bioresources Technology 2019, 277, 184. https://doi.org/10.1016/j.biortech.2019.01.036

[8] Lamm S.S., Mahari W.A.W., Ma N.L. et al.: Chemosphere 2019, 230, 294. https://doi.org/10.1016/j.chemosphere.2019.05.054

[9] Undri A., Meini S., Rosi L. et al:: Journal of Analytical and Applied Pyrolysis 2013, 103, 149. 
https://doi.org/10.1016/j.jaap.2012.11.011

[10] Undri A., Rosi L., Frediani M. et al.: Journal of Analytical and Applied Pyrolysis 2014, 108, 86. http://dx.doi.org/10.1016/j.jaap.2014.05.013

[11] Rosi L., Bartoli M., Frediani M.: Waste Management 2018, 73, 511.

http://dx.doi.org/10.1016/j.wasman.2017.04.037

[12] Qadariyah L., Mahfud M., Prihatini P. et al.: Modern Applied Science 2015, 9, 74. http://dx.doi.org/10.5539/mas.v9n7p74

[13] Suriapparao D.V., Boruah B., Raja D. et al.: Fuel Processing Technology 2018, 175, 64. https://doi.org/10.1016/j.fuproc.2018.02.019

[14] Mahari W.A.W., Chong C.T., Lam W.H. et al.: Energy Conversion and Management 2018, 171, 1292. https://doi.org/10.1016/j.enconman.2018.06.073

[15] Duan D., Wang Y., Dai L. et al.: Bioresources Technology 2017, 241, 207.

http://dx.doi.org/10.1016/j.biortech.2017.04.104

[16] Zhao Y., Wang Y., Duan D. et al.: Bioresources Technology 2018, 249, 69.

http://dx.doi.org/10.1016/j.biortech.2017.09.184

[17] Butlewski K.: "Combined Biomass Gasification and Anaerobic Digestion for the Synergic Effect in Power Production for the Local Application", Proceedings 25th European Biomass Conference and Exhibition, Amsterdam, Holland, 6-9 June 2016, 884.

http://www.etaflorence.it/proceedings/?detail=12384

[18] PL Pat. 227318 (2013).

Received 6 VI 2019. 